\title{
Evaluation of Awareness, Knowledge and Attitudes regarding Common Rheumatic Diseases (Rheumatoid Arthritis and Systemic Lupus Erythematous) in Sohag Governorate
}

\author{
${ }^{1}$ Ahmed Mohammed El Saman, ${ }^{2}$ Eman Roshdy Mohamed, ${ }^{1}$ Asmaa Khalifa, ${ }^{3}$ El- \\ Zahraa Mohammed Meghezel, ${ }^{1}$ Ahmed Roshdy Al-Agamy Radwan \\ ${ }^{1}$ Department of Rheumatology, ${ }^{2}$ Department of public Health and Community Medicine, \\ ${ }^{3}$ Department of Gastroenterology and Hepatology, Sohag University
}

\begin{abstract}
Background: Rheumatoid arthritis (RA) is one of the commonest autoimmune diseases. It affects about $1 \%$ of the population worldwide. Systemic lupus erythematosis (SLE) is a chronic autoimmune disease which vary from mild to life-threatening condition. Objective: To measure awareness, knowledge and attitude of community members attending health centers toward rheumatic diseases. Method: A cross-sectional community-based study was conducted in Sohag governorate in Upper Egypt. Potential study participants were recruited from urban health centers in different cities and villages in Sohag governorate. Data were collected using a structured questionnaire. Results: Total 2,168 participants between 19 and 66 years old were recruited, 1,098 (50.6\%) were males, $445(20.5 \%)$ were illiterate, $596(27.5 \%)$ reported to be currently unemployed, 702 $(32.4 \%)$ of participants were a slum area resident, $769(35.5 \%)$ reported either themselves or one of their family members having a rheumatic disease, 955(44\%) of participants reported that rheumatology is a part of orthopedic, only $882(40.7 \%)$ of the participants believed that drugs which are used in treatment of rheumatic disease are safe. Awareness and knowledge of rheumatic diseases are significantly higher among females, participants with higher education level, working for cash, single participants and urban residents. Conclusion: Awareness and knowledge of the studied sample in Sohag city regarding rheumatic diseases need to be improved through extensive mass educational and learning programs
\end{abstract}

Keywords: Awareness, Knowledge, Attitude, Rheumatic diseases

Corresponding author: Eman Roshdy Mohamed roshdyeman@gmail.com

\section{Introduction}

Rheumatoid arthritis (RA) is one of the commonest autoimmune diseases. It affects about $1 \%$ of the population worldwide. ${ }^{1}$ The prevalence of RA differ widely among different countries, while it is $1 \%$ in north America, it decreases to $0.2-0.3 \%$ in China, Japan, north-west Greece, rural Africa and Egypt. ${ }^{2}$ Not only the prevalence of the disease which varies among different continents, races, ages and socioeconomic levels, but also the disease pattern, knowledge, attitude and practice (KAP). ${ }^{3}$ Systemic lupus erythematosus (SLE) is a relatively uncommon chronic autoimmune disease which varies from mild to lifethreatening conditoin. There is no agreement about the exact definition of the disease. The prevalence in the developed world is 24/100,000 population. Studies in countries which include predominantly white races showed lower prevalence rates (in comparison to those conducted among Afro-Caribbeans, Asians and Hispanics). ${ }^{4}$ In Egypt there is no clear 
data about the exact prevalence of the disease in adults. 5,6

Chronic diseases management and treatment require clear and organized planning to raise the awareness about disease nature, risk factors, complications and prognostic factors. The patient should have a full picture of his disease; moreover, he should participate in the choosing of treatment strategy. This will result in improving attitudes and behaviors of patients and subsequently improve disease outcome. Self-management skills are crucial for improving patient compliance to treatment and follow-up of the disease. ${ }^{7}$ Several studies displayed that, KAP of chronic rheumatic diseases are related to patient's age and education, and those people who are suffering from those diseases have insufficient information. More work is needed to be achieved in this field for the reason that KAP were deeply influenced by scoioeconomic, demographic levels and also, by the disease pathological pattern. ${ }^{8-10}$ To the best of our knowledge, this is the first study to assess KAP of rheumatic diseases (RA, SLE) in Upper Egypt.

We aimed to provide a full data about the present situation of those common rheumatic diseases, which can be used for the future planning of awareness raising and education programs in Sohag Governorate.

\section{Method}

Study design and study population: This is a cross-sectional community-based study conducted in Sohag governorate. Sohag is a densely populated province in Upper Egypt; with approximately 5.1 million inhabitants (according to governmental records in January 2019). Female and male individuals between 19 and 66 years of age who visited the urban centers in Sohag governorate during the period from January 2018 to June, were invited to participate in the study.
Sohag contains 12 urban centers (cities). The field part of the study was about 6 months, during this period we visited each center twice and did a total coverage for all center's visitors who are eligible to participate in the study. We recruited 150-200 participants from each urban center, the total number of participants was 2168 .

Data were collected from the questionnaire through either selfanswering of the participants of the Arabic version of the questionnaire, or through face-to-face interviews for patients who are illiterate The questionnaire was in two versions: English version which was used in the study analysis and Arabic version answered by the participants, the items of the questionnaire were taken from some papers that used validated questionnaire. ${ }^{3,7,8}$ The questionnaire is divided into five parts: Basic information about the participants; General knowledge about rheumatic diseases; Knowledge about rheumatoid arthritis; Knowledge about systemic lupus; Attitude towards patients with rheumatic diseases.

To provide "knowledge and awareness score" for each participant, we gave each "right answer" a score of (1), each "wrong answer" a score of (0), and each "I do not know "a score of (0) then we summated these answers, giving a total score ranging from 0 to 87 . The accuracy is the percentage of the true score of each participant to the highest score of 87 , according to the accuracy calculated from questionnaire scoring system; we ranked our participants into five levels: Excellent, good, average, bad and very bad.

Statistical analysis: Statistical analysis was performed with IBM SPSS Statistics, version 22. Qualitative data were expressed as number and percentages, while the quantitative data were expressed as mean $\pm \mathrm{SD}$. We tested the data for normality by Shapiro-Wilk 
test that direct us to use parametric tests chi-square such as independent $t$ test. We used the

Table 1: Demographic data of the study population

\begin{tabular}{llrrrr}
\hline & \multicolumn{1}{c}{ Item } & $\begin{array}{c}\text { Males } \\
\mathbf{1 , 0 9 8} \\
\mathbf{( 5 0 . 6 \% )}\end{array}$ & $\begin{array}{c}\text { Females } \\
\mathbf{1 , 0 7 0}(\mathbf{4 9 . 4 \% )})\end{array}$ & $\begin{array}{c}\text { Total } \\
\mathbf{2 , 1 6 8} \\
(\mathbf{1 0 0 \%})\end{array}$ & $\begin{array}{c}\text { P } \\
\text { value }\end{array}$ \\
\hline Age & Mean + SD & $41.58 \pm 13.56$ & $41.07 \pm 13.64$ & $41.33 \pm 13.6$ & 0.384 \\
\hline Education & Illiterate & $197(18.4)$ & $248(22.6)$ & $445(20.5)$ & \\
level: & Primary education & $244(22.8)$ & $225(20.5)$ & $469(21.6)$ & \\
N (\%) & Secondary education & $366(34.2)$ & $411(37.4)$ & $777(35.8)$ & $\mathbf{0 . 0 0 5}$ \\
& Graduate university education & $234(21.9)$ & $185(16.8)$ & $419(19.3)$ & \\
& Postgraduate education & $29(2.7)$ & $29(2.6)$ & $58(2.7)$ & \\
\hline Residence & Urban & $375(34.2)$ & $332(31.0)$ & $707(32.6)$ & \\
N (\%) & Rural & $391(35.6)$ & $368(34.4)$ & $759(35.0)$ & 0.082 \\
& Slum & $332(30.2)$ & $370(34.6)$ & $702(32.4)$ & \\
\hline Marital & Single & $131(11.9)$ & $110(10.3)$ & $241(11.1)$ & \\
Status & Married & $724(65.9)$ & $551(51.5)$ & $1275(58.8)$ & 0.076 \\
N (\%) & Divorced & $140(12.8)$ & $210(19.6)$ & $350(16.1)$ & \\
& Widow & $103(9.4)$ & $199(18.6)$ & $302(13.9)$ & \\
\hline Occupation & Currently working & $869(79.1)$ & $703(65.7)$ & $1572(72.5)$ & $<\mathbf{0 . 0 0 1}$ \\
N (\%) & Not working & $229(20.9)$ & $367(34.3)$ & $596(27.5)$ & \\
\hline
\end{tabular}

Table 2. General knowledge about rheumatology

\begin{tabular}{|c|c|c|c|}
\hline Item & $\begin{array}{c}\text { Yes } \\
\mathbf{N}(\%)\end{array}$ & $\begin{array}{c}\text { No } \\
\mathbf{N}(\%)\end{array}$ & $\begin{array}{c}\text { I do not know } \\
\mathbf{N}(\%) \\
\end{array}$ \\
\hline Rheumatology is the same as Orthopedics & $955(44.0)$ & $969(44.7)$ & $244(11.3)$ \\
\hline Rheumatology is a branch of Orthopedics & $425(19.6)$ & $1023(47.2)$ & $720(33.2)$ \\
\hline Rheumatology is a branch of Internal Medicine & $482(22.2)$ & $1002(46.2)$ & $684(31.5)$ \\
\hline Rheumatology is the same as Immunology & $472(21.8)$ & $865(39.9)$ & $831(38.3)$ \\
\hline Rheumatology is directly related to Rehabilitation & $986(45.5)$ & $756(34.9)$ & $426(19.6)$ \\
\hline Rheumatology is a separate branch of medicine & $718(33.1)$ & $716(33.0)$ & $734(33.9)$ \\
\hline \multicolumn{4}{|l|}{ The cause of rheumatic diseases are: } \\
\hline - Genetic & $918(42.3)$ & $820(37.8)$ & $430(19.8)$ \\
\hline - Inflammatory & $1114(51.4)$ & $598(27.6)$ & $456(21.0)$ \\
\hline - $\quad$ Auto-immune & $774(35.7)$ & $688(31.7)$ & $706(32.6)$ \\
\hline - Degenerative & $876(40.4)$ & $662(30.5)$ & $630(29.1)$ \\
\hline $\begin{array}{c}\text { The aims of investigations for rheumatic patients: } \\
-\quad \text { To monitor disease activity } \\
-\quad \text { To monitor disease complications }\end{array}$ & $\begin{array}{l}930(42.9) \\
935(43.1)\end{array}$ & $\begin{array}{l}491(22.6) \\
867(40.0)\end{array}$ & $\begin{array}{l}747(34.5) \\
366(16.9)\end{array}$ \\
\hline
\end{tabular}

test to calculate the differences across groups in categorical variables.

\section{Ethical Consideration}

The study protocol got the approval of the ethical committee at Sohag faculty of medicine. We elucidated all the study details and related terminologies were clearly defined to the study participants.
Written informed consent was obtained from each respondent before their interview

\section{Results}

Table 1 shows descriptive characteristics of the total study population, total 2168 participants between 19 and 66 years old 
Table 3: Knowledge about rheumatic diseases treatment

\begin{tabular}{llr}
\hline & & No (\%) \\
\hline $\begin{array}{l}\text { Do you think that treatment of Curative in most cases } \\
\text { rheumatic diseases is? }\end{array}$ & $\begin{array}{l}\text { Can treat symptoms and stop disease } \\
\text { progression in most cases }\end{array}$ & $800(36.9)$ \\
& I do not know & $410(18.9)$ \\
\hline $\begin{array}{l}\text { Do you think that drugs used in } \\
\text { rheumatology are? }\end{array}$ & Safe & \\
& & $882(40.7)$ \\
& Toxic & $618(28.5)$ \\
& I do not know & $668(30.8)$ \\
\hline $\begin{array}{l}\text { Do you think that drugs used in } \\
\text { rheumatology are? }\end{array}$ & $\begin{array}{l}\text { Expensive expensive } \\
\end{array}$ & $620(28.6)$ \\
& Of moderate cost & $424(19.6)$ \\
& Very cheap & $571(26.3)$ \\
& Some are cheap & $196(9.0)$ \\
\end{tabular}

Table 4: Knowledge about rheumatoid arthritis:

\begin{tabular}{llr}
\hline & & No (\%) \\
\hline Have you ever heard about RA? & Yes & $1208(55.7)$ \\
& No & $960(44.3)$ \\
\hline How did you hear about RA? & Not mentioned & $960(44.3)$ \\
& From a doctor & $145(6.7)$ \\
& From media & $324(14.9)$ \\
& From a friend & $384(17.7)$ \\
& From the internet & $120(5.5)$ \\
& From a patient & $235(10.8)$ \\
\hline Do you think that RA is: & An infectious disease & $321(14.8)$ \\
& A genetic disease & $401(18.5)$ \\
& An auto immune diseases & $307(14.2)$ \\
& An inflammatory diseases & $725(33.4)$ \\
& I do not know & $414(19.1)$ \\
\hline
\end{tabular}

Table 5: Rheumatoid arthritis epidemiology:

\begin{tabular}{|c|c|c|c|}
\hline \multirow{5}{*}{ Regarding sex: } & & & No(\%) \\
\hline & \multicolumn{2}{|c|}{ RA is more common in females } & $513(23.7)$ \\
\hline & \multicolumn{2}{|c|}{$\mathrm{RA}$ is more common in males } & $730(33.7)$ \\
\hline & \multicolumn{2}{|c|}{$\mathrm{RA}$ is equal in both gender } & $349(16.1)$ \\
\hline & \multicolumn{2}{|l|}{ I do not know } & $576(26.6)$ \\
\hline \multirow[t]{5}{*}{ Regarding age: } & \multicolumn{2}{|l|}{ RA can affect all ages } & $735(33.9)$ \\
\hline & \multicolumn{2}{|c|}{ RA affects only children } & $205(9.5)$ \\
\hline & \multicolumn{2}{|c|}{ RA affects only middle-aged persons } & $404(18.6)$ \\
\hline & \multicolumn{2}{|c|}{ RA affects only old aged persons } & $380(17.5)$ \\
\hline & \multicolumn{2}{|c|}{ I do not know } & $444(20.5)$ \\
\hline \multirow{4}{*}{$\begin{array}{l}\text { Do you think that } \\
\text { RA is: }\end{array}$} & \multicolumn{2}{|c|}{ A completely curable diseases } & $570(26.3)$ \\
\hline & \multicolumn{2}{|c|}{ A treatable disease but complete cure is impossible } & $810(37.4)$ \\
\hline & \multirow{2}{*}{\multicolumn{2}{|c|}{$\begin{array}{l}\text { A non-treatable disease, we can just relieve its symptoms } \\
\text { I do not know }\end{array}$}} & $384(17.7)$ \\
\hline & & & $404(18.6)$ \\
\hline \multicolumn{4}{|c|}{$\begin{array}{ll}\text { were recruited for the study, } 1,098 & \text { were statistical signif } \\
(50.6 \%) \text { were males, } 445(20.5 \%) \text { were } & \text { between males and fer } \\
\text { illiterate, 596 }(27.5 \%) \text { reported to be } & \text { education level, emplo } \\
\text { currently unemployed. } 702(32.4 \%) \text { of } & \text { of the } 2,168 \text { participa } \\
\text { participants being a slum resident. There } & \text { reported having a rl }\end{array}$} \\
\hline
\end{tabular}

Table 6: Parts of the body can be affected by rheumatoid arthritis: 


\begin{tabular}{lrrr}
\hline \multicolumn{1}{c}{ Item } & \multicolumn{1}{c}{ Yes } & \multicolumn{1}{c}{ No } & \multicolumn{1}{c}{ I do not know } \\
& \multicolumn{1}{c}{$\mathbf{N}(\boldsymbol{\%})$} & \multicolumn{1}{c}{$\mathbf{N}(\boldsymbol{\%})$} & \multicolumn{1}{c}{$(\boldsymbol{\%})$} \\
\hline Joints & $808(37.3)$ & $1145(52.8)$ & $215(9.9)$ \\
Musculoskeletal system & $1116(51.5)$ & $605(27.9)$ & $447(20.6)$ \\
Gastrointestinal tract & $579(26.7)$ & $896(41.3)$ & $693(32.0)$ \\
Kidneys & $683(31.5)$ & $846(39.0)$ & $639(29.5)$ \\
Liver & $230(10.6)$ & $1113(51.3)$ & $825(38.1)$ \\
Central nervous system & $537(24.8)$ & $996(45.9)$ & $635(29.3)$ \\
All body systems & $367(16.9)$ & $1280(59.0)$ & $521(24.1)$ \\
\hline
\end{tabular}

Table 7: General knowledge about SLE

\begin{tabular}{|c|c|c|c|c|}
\hline Item & & $\begin{array}{c}\text { Yes } \\
\mathbf{N}(\%) \\
\end{array}$ & $\begin{array}{c}\text { No } \\
\mathbf{N}(\%) \\
\end{array}$ & $\begin{array}{c}\text { I do not know } \\
N(\%)\end{array}$ \\
\hline \multirow{5}{*}{$\begin{array}{l}\text { What are the } \\
\text { possible causes of } \\
\text { SLE? }\end{array}$} & Inherited genes & $1089(50.2)$ & $684(31.5)$ & $395(18.2)$ \\
\hline & A hidden infection & $846(39.0)$ & $584(26.9)$ & $738(34.0)$ \\
\hline & Female sex & $1158(53.4)$ & $471(21.7)$ & $539(24.9)$ \\
\hline & Environmental pollution & $964(44.5)$ & $667(30.8)$ & $537(24.8)$ \\
\hline & An auto-immune process & $1000(46.1)$ & $729(33.6)$ & $439(20.2)$ \\
\hline \multirow{5}{*}{$\begin{array}{l}\text { Common } \\
\text { symptoms of } \\
\text { SLE: }\end{array}$} & Fever & $942(24.5)$ & $532(24.5)$ & $694(32.0)$ \\
\hline & Skin rash & $1117(51.5)$ & $433(20.0)$ & $618(28.5)$ \\
\hline & Swollen joints & $1219(56.2)$ & $412(19.0)$ & $537(24.8)$ \\
\hline & Extreme fatigue & $856(39.5)$ & $623(28.7)$ & $689(3.8)$ \\
\hline & All of the above & $467(21.5)$ & $907(41.8)$ & 794 (36.6) \\
\hline \multirow{7}{*}{$\begin{array}{l}\text { Which of these } \\
\text { organs are } \\
\text { commonly } \\
\text { affected by SLE? }\end{array}$} & Kidneys & $689(31.8)$ & $913(42.1)$ & $566(26.1)$ \\
\hline & Lungs & $647(29.8)$ & $918(42.3)$ & $603(27.8)$ \\
\hline & CNS & $812(37.5)$ & $669(30.9)$ & $687(31.7)$ \\
\hline & Skin & $1041(48.0)$ & $481(22.2)$ & $646(29.8)$ \\
\hline & Joints & $1396(64.4)$ & $357(16.5)$ & 415 (19.2) \\
\hline & Blood & $804(37.1)$ & $659(30.4)$ & $705(32.5)$ \\
\hline & All of the above & $371(17.1)$ & $1156(53.3)$ & $641(29.6)$ \\
\hline
\end{tabular}

Table 8: Diagnosis and treatment of SLE

\begin{tabular}{llrrr}
\hline \multicolumn{1}{c}{ Item } & \multicolumn{1}{c}{ Yes } & \multicolumn{1}{c}{$\begin{array}{c}\text { No } \\
\text { N (\%) }\end{array}$} & $\begin{array}{c}\text { I do not know } \\
\text { N (\%) }\end{array}$ \\
\hline How is SLE & By clinical assay & $992(45.8)$ & $776(35.8)$ & $400(18.5)$ \\
diagnosed? & By imaging studies & $1115(51.4)$ & $729(33.6)$ & $324(15.0)$ \\
& By laboratory investigations & $1172(54.1)$ & $687(31.7)$ & $299(14.3)$ \\
How is SLE & All of the above & $684(31.5)$ & $1000(46.1)$ & $484(22.3)$ \\
treated? & By surgery & $909(41.9)$ & $874(40.3)$ & $385(17.8)$ \\
& By radiation therapy & $804(37.1)$ & $691(31.9)$ & $673(31.0)$ \\
& By anti-inflammatory medicines & $1145(52.8)$ & $658(30.4)$ & $365(16.8)$ \\
& By drugs specific for lupus & $1222(56.4)$ & $484(22.3)$ & $462(21.3)$ \\
& Just by palliative treatment & $646(29.8)$ & $882(40.7)$ & $640(29.5)$ \\
& $\begin{array}{l}\text { None of the above, lupus is non- } \\
\text { treatable disease }\end{array}$ & $370(17.1)$ & $1659(76.5)$ & $139(6.4)$ \\
\hline
\end{tabular}

(either the participants themselves 210 $(9.7 \%)$ or one of the family members 559 (25.8\%). (Figure 1). Table 2 shows the general concept of our studied population about rheumatology. 955 (44\%) of our participants reported that rheumatology is a part of orthopedics, Regarding the cause of rheumatic diseases, more than half of subjects $(51.7 \%)$ related rheumatic diseases to inflammatory causes, but only $35.7 \%$ of them related rheumatology to auto-immunity. On the other hand, $40.4 \%$ of our participant related rheumatic diseases to degenerative cause which is a wrong answer. More than $40 \%$ agreed that investigations can be used to monitor disease activity or complications, but another $40 \%$ denied its importance. Table 3 shows the knowledge of the study participants regarding rheumatic diseases treatment. The effect of drugs were expected to control the diseases by more

\section{Table 9: Relation with someone that has rheumatic disease:}




\begin{tabular}{|c|c|c|}
\hline & & No $(\%)$ \\
\hline \multirow{6}{*}{$\begin{array}{l}\text { Do you or a family member living in your } \\
\text { household have one of the above-mentioned } \\
\text { rheumatic diseases? } \\
\text { If yes, who? }\end{array}$} & Yes & $769(35.5)$ \\
\hline & No & $718(33.1)$ \\
\hline & I do not know & $681(31.4)$ \\
\hline & The question is not applicable & $1399(64.5)$ \\
\hline & Myself & $210(9.7)$ \\
\hline & One or more of my family members & $559(25.8)$ \\
\hline \multirow{5}{*}{$\begin{array}{l}\text { Would you likely marry a patient with one of } \\
\text { the above-mentioned rheumatic diseases? }\end{array}$} & Strongly agree & $314(14.5)$ \\
\hline & Agree & $428(19.7)$ \\
\hline & Undecided & $508(23.4)$ \\
\hline & Disagree & $627(29.0)$ \\
\hline & I do not know & $291(13.4)$ \\
\hline \multirow{5}{*}{$\begin{array}{l}\text { Would you likely live in the same place with a } \\
\text { person with rheumatic disease? }\end{array}$} & Strongly agree & $349(16.1)$ \\
\hline & Agree & $510(23.5)$ \\
\hline & Undecided & $379(17.5)$ \\
\hline & Disagree & $407(18.8)$ \\
\hline & I do not know & $523(24.1)$ \\
\hline \multirow{5}{*}{$\begin{array}{l}\text { Would you likely play or work with a patient } \\
\text { with rheumatic disease? }\end{array}$} & Strongly agree & $349(16.1)$ \\
\hline & Agree & $404(18.6)$ \\
\hline & Undecided & $790(36.4)$ \\
\hline & Disagree & $407(18.8)$ \\
\hline & I do not know & $218(10.1)$ \\
\hline
\end{tabular}

Table 10: What if you have a rheumatic disease?

\begin{tabular}{|c|c|c|c|c|c|c|}
\hline & $\begin{array}{l}\text { Strongly } \\
\text { Agree } \\
\text { N }(\%) \\
\end{array}$ & $\begin{array}{l}\text { Agree } \\
\text { N }(\%)\end{array}$ & $\begin{array}{c}\text { Undecided } \\
\text { N (\%) } \\
\end{array}$ & $\begin{array}{l}\text { Disagree } \\
\text { N }(\%) \\
\end{array}$ & $\begin{array}{c}\text { Strongly } \\
\text { Disagree } \\
\mathbf{N}(\%) \\
\end{array}$ & $\begin{array}{l}\text { I do not } \\
\text { know } \\
\text { N }(\%) \\
\end{array}$ \\
\hline $\begin{array}{l}\text { Would you likely inform } \\
\text { your wife/husband that } \\
\text { you have a rheumatic } \\
\text { disease }\end{array}$ & $501(23.1)$ & 376 (17.3) & $444(20.5)$ & $416(19.2)$ & 0 & 431 (19.9) \\
\hline $\begin{array}{l}\text { Would you likely inform } \\
\text { your friend that you } \\
\text { have a rheumatic disease }\end{array}$ & $501(23.1)$ & $187(8.6)$ & $444(20.5)$ & $416(19.2)$ & 338 (15.6) & $282(13.0)$ \\
\hline $\begin{array}{l}\text { Would you likely inform } \\
\text { your colleagues that you } \\
\text { have a rheumatic disease }\end{array}$ & $501(23.1)$ & $187(8.6)$ & $444(20.5)$ & $657(30.3)$ & 273 (12.6) & 106 (4.9) \\
\hline
\end{tabular}

than one third (36.9\%), only $40.7 \%$ of the participants believed that drugs which are used in treatment of rheumatic disease are safe, and $31 \%$ denied any previous knowledge in this point. The cost of the drugs was a matter of conflict, with only one sixth $(16.5 \%)$ reached the correct answer (some are cheap, some are expensive).

Table (4), shows the general knowledge about RA among the study population. Of the 2168 participants, 1208 (55.7\%) reported having heard of RA. However, the most common source of RA was "heard from a friend" (31.8\%), with only $12 \%$ heard about it "from a physician".
About $14.2 \%$ of participants related RA to an autoimmune cause, while over $33 \%$ thought that it is an inflammatory disease. Table (5), explores the epidemiology of RA, $23.7 \%$ of participants reported that RA is more common among females, and $33.9 \%$ reported that RA can affect all age groups, regarding the curability of RA, $37.4 \%$ of the participant stated that RA is "a treatable disease but a complete cure is impossible", while $26.3 \%$ stated that it's a completely curable disease", while about $18.6 \%$ of the participant did not know. Table (6), regarding the parts of the body

Table 11: What would you do for your management if you have a rheumatic disease? 


\begin{tabular}{cccc} 
Undecided & Disagree & $\begin{array}{c}\text { Strongly } \\
\text { Disagree } \\
\mathbf{N}(\%)\end{array}$ & $\begin{array}{c}\text { I do not } \\
\text { know } \\
\mathbf{N}(\%)\end{array}$ \\
\hline $\mathbf{N}(\%)$ & $\mathbf{N}(\%)$ & $132(6.1)$ & $176(8.1)$
\end{tabular}

$244(11.3) \quad 363(16.7) \quad 519(23.9) \quad 37(1.7)$

\begin{tabular}{|c|c|c|}
\hline & $\begin{array}{c}\text { Strongly } \\
\text { Agree } \\
\text { N }(\%)\end{array}$ & \\
\hline $\begin{array}{l}\text { I will ask for medical } \\
\text { advice }\end{array}$ & $732(33.8)$ & 696 \\
\hline $\begin{array}{l}\text { I will buy some } \\
\text { medication directly } \\
\text { from the pharmacy }\end{array}$ & $603(27.8)$ & 402 \\
\hline $\begin{array}{l}\text { I will ask a person } \\
\text { who can remove (evil } \\
\text { spirits) }\end{array}$ & $589(27.2)$ & 280 \\
\hline $\begin{array}{l}\text { I will ask for } \\
\text { physiotherapy }\end{array}$ & $721(33.3)$ & \\
\hline $\begin{array}{l}\text { I will try some herbal } \\
\text { and alternative } \\
\text { medicines }\end{array}$ & $808(37.3)$ & \\
\hline \multicolumn{3}{|c|}{$\begin{array}{l}\text { affected by RA, only } 16.9 \% \text { of } \\
\text { participants agreed that it can affect } \\
\text { body systems; compared to } 51.5 \% \text { W } \\
\text { stated that it is a disease } \\
\text { musculoskeletal system mainly. }\end{array}$} \\
\hline \multicolumn{3}{|c|}{$\begin{array}{l}\text { Table 12: Evaluation of rheumatic dise } \\
\text { awareness and knowledge score }\end{array}$} \\
\hline $\begin{array}{r}\text { Level } \\
\end{array}$ & No & $\%$ \\
\hline Excellent $(>80 \%$ & 0 & 0 \\
\hline Good $(60-80 \%)$ & 268 & 12.4 \\
\hline Average $(40-60 \%$ & 537 & 24.8 \\
\hline Bad (20-40\%) & 1050 & 48.4 \\
\hline Very bad $(<20 \%$ & 313 & 14.4 \\
\hline
\end{tabular}

Table 13: Evaluation of rheumatic disease attitude score

\begin{tabular}{lrr}
\hline Level & \multicolumn{1}{c}{ No } & \multicolumn{1}{c}{$\%$} \\
\hline Excellent $(>\mathbf{8 0 \%})$ & 0 & 0 \\
Good $(\mathbf{6 0 - 8 0 \%})$ & 256 & 11.8 \\
Average $(\mathbf{4 0 - 6 0 \% )}$ & 549 & 25.3 \\
Bad (20-40\%) & 1031 & 47.6 \\
Very bad $(<\mathbf{2 0 \%})$ & 332 & 15.3 \\
\hline
\end{tabular}

Table (7), shows the general knowledge about SLE among our study participants. The cause of SLE was multifactorial as decided by most of our subjects, with female sex and genetics plays the most important rules (agreed by $53.4 \%$ and $50.2 \%$ of our subjects respectively). Although $46 \%$ of them agreed that SLE is an autoimmune disease. Subjects

\begin{abstract}
medication directly
I will ask for

I will try some herbal medicines participants agreed that it can affect all body systems; compared to $51.5 \%$ who stated that it is a disease of
\end{abstract}

Table 12: Evaluation of rheumatic disease

\section{Level}

Table 14: Factors affecting knowledge and awareness of the study population about rheumatic diseases

\begin{tabular}{lllc}
\hline Item & Score & P value \\
\hline Sex & Male & $28.98 \pm 12.80$ & $<0.001$ \\
\hline
\end{tabular}

agreed that, swollen joints $(56.2 \%)$ and skin rash $(51.5 \%)$ were the most common symptoms of SLE. This was reflected to the other questions, with $64.4 \%$ of them agreed that SLE can affect joints, $48 \%$ agreed that SLE can affect skin, compared to only $17.1 \%$ who agreed that SLE is a systemic disease which can affect all body systems. Table (8), Regarding SLE diagnosis, nearly $31.5 \%$ of our participants thought that it need a combination of clinical, laboratory and imaging studies. More than one half $(56.4 \%)$ agreed that SLE is treated by drugs specific for lupus

Tables (9, 10, and 11) show the attitude toward individuals with rheumatic diseases, on which around one third of our participants had at least one family member with one of the rheumatic diseases, among them $9.7 \%$ had the disease themselves. However, a substantial proportion of participants had negative attitudes towards individuals with rheumatic diseases. To the extent that, every third participant reported not to marry a person with a rheumatic disease. Every fifth participant reported not to play/work or live in the same place with a person with a rheumatic disease. This was out the

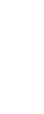




\begin{tabular}{llll}
\hline & Female & $31.55 \pm 14.47$ & \\
\hline Education & Illiterate & $14.46 \pm 3.83$ & \\
& Primary education & $23.91 \pm 5.72$ & \\
& Secondary education & $31.29 \pm 6.55$ & $<0.001$ \\
& University graduate education & $48.26 \pm 9.69$ & \\
& Postgraduate education & $58.50 \pm 1.22$ & \\
\hline Work & Working & $28.74 \pm 12.92$ & $<0.001$ \\
& Not working & $34.23 \pm 14.89$ & \\
\hline Residence & Urban & $34.90 \pm 13.65$ & $<0.001$ \\
& Rural & $30.01 \pm 15.25$ & \\
& Slum & $25.82 \pm 10.02$ & \\
\hline Marital & Single & $47.58 \pm 11.92$ & \\
status & Married & $29.21 \pm 13.97$ & \\
& Divorced & $24.65 \pm 5.74$ & \\
& Widow & $27.29 \pm 9.28$ & \\
\hline
\end{tabular}

reflected by their decision not to inform their contacts if they had a rheumatic disease, with only $23 \%$ agreed strongly to do so, while $19.2 \%$ of participants decided not to inform their wife/husband, $34.8 \%$ decided not to inform their friends and $42.9 \%$ decided not to inform their colleagues. Although the majority of the participants agreed to seek medical advice if they had a rheumatic disease (65.9\%). Other non-medical routes were also agreed by many of them such as buying some over the counter medicines (46.3\%), ask for removing "evil spirits" or even $(39.9 \%)$, ask for physiotherapy $(41 \%)$, and try herbal and alternative medicine measures $(43.3 \%)$.

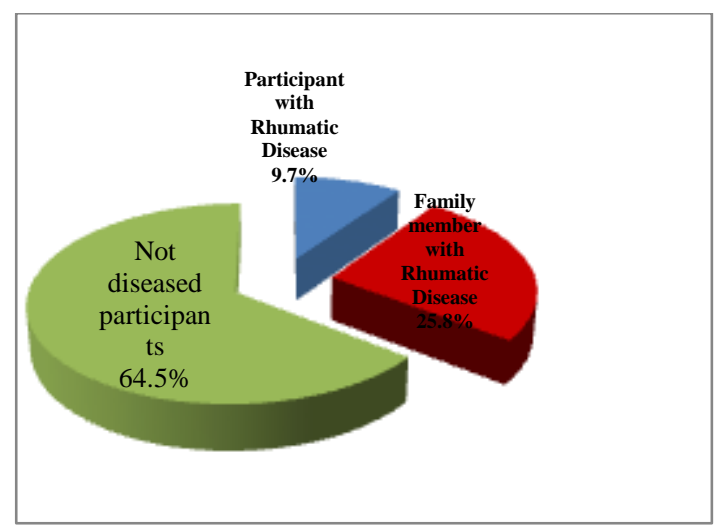

Figure (1): The prevalence of rheumatic disease among study participants

Table (12), regarding evaluation of rheumatic disease awareness and knowledge score, we revealed that the majority of the participants fell in the "bad level (48.4\%)" and "average" levels
(24.8\%), with no one had "excellent" level of knowledge regarding rheumatic diseases. Table (13), shows factors affecting knowledge and awareness of the study population about rheumatic diseases: We found that awareness and knowledge of rheumatic diseases are significantly higher among females. Regarding education level, there is a steady increase in the awareness with the rise of education level, with a highly significant relation. Non-working and single participants had significantly higher knowledge compared to married or working ones. Lastly, regarding residence, urban people had the highest knowledge scores, followed by rural, and lastly those came from slum areas.

\section{Discussion}

Although the prevalence of diseases like RA and SLE, in Egypt in general and Upper Egypt in particular are not well studied, these diseases are considered as the most prevalent rheumatic diseases worldwide. Spreading of knowledge about these diseases in the poor areas and among population of poor education and socioeconomic levels could modify the disease track towards better scenarios. This study shed light on the present KAP regarding those diseases in upper Egypt and suggest overtures to improve the current situation. $^{3}$

Male: female ratio in our study was 1:1. One fifth of the participants were illiterate. Educational level, employment 
and marital status were greater in males than females with a significant difference. This distribution can be attributed to the patriarchal community nature in upper Egypt. We found in our study, that about one third of the participants reported having a rheumatic disease themselves or one of the family members has a rheumatic disease. This was consonant with results from Usenbo et al. ${ }^{3}$

At variance of expectations, our study revealed that more than one third participants were able to sharply differentiate between orthopedics and rheumatology. Moreover, nearly one third of participants considered that rheumatology is related to autoimmunity. An analogous study was performed in Netherland with a dissimilar educational, ethnic and social horizon. ${ }^{11}$

Severo and his colleagues conducted a study in Portugal with a similar number of participants to ours and their main concern was RA, SLE, osteoporosis, beside other rheumatic diseases. This survey unveiled the limited knowledge concerning rheumatic diseases at the general population: there were obstacles of differentiation between rheumatic diseases, and more than half of the participants thought that rheumatic diseases are not curable. One quarter of the study participants had a false general concepts about rheumatic diseases and less than $1 / 3$ did not have thorough knowledge about rheumatic diseases. ${ }^{7}$

More than half of our respondents were aware of RA, and around 1/8 heard about it "from a physician", a comparable study was conducted in Iraq with a similar cultural background of the participants demonstrated that one third of the study participants have no idea about their disease, one fifth didn't understand the aim for the investigations, about half of them did not neither distinguish their medication, nor its adverse effects. In this study all the contributors had RA and they are frequently visiting their physician. They found a poor correlation between patients' educational level and the disease activity. They elicited that, neither the educational level nor the frequency of clinic visits had an effect on the disease knowledge and awareness. This assumption may be interpreted by the relatively low educational level of the participants in comparison to ours. ${ }^{12}$

Near half of the participants agreed that SLE is an autoimmune disease. Swollen joints and skin rash were the commonest manifestations approved by the participants as common symptoms of SLE. Less than $1 / 3$ of participants supposed that SLE diagnosis requires a combination of clinical, laboratory and imaging studies. More than half agreed that SLE is treated by drugs specific for lupus. Most of our participants answered wrongly that SLE is either more common among males or equal in both sexes. Most of our participants stated that steroid is needed in SLE treatment.

Lama, et al. carried out a similar study but with limited number of participants (only 29); those who are following regularly in the outpatient clinic. They revealed that less than $1 / 3$ had high knowledge of their disease, more than half had intermediate knowledge and only $3.5 \%$ their knowledge was considered as inadequate. With regards of SLE etiopathogenesis they found that less than $2 / 3$ are unknowledgeable about this field. Only $1 / 10$ were able to describe properly how medications work. Only $6.9 \%$ of their patients were aware of the immunosuppressive effect of corticosteroids. They deduced that most of their SLE patients had a knowledge that can be considered as intermediate quality. This study was done in Puro with educational and socioeconomic conditions similar or may be better than ours, but the sample size and the inclusion of only SLE patient could elucidate the results difference. ${ }^{13}$ 
Rheumatic conditions are chronic diseases and they require a continuous adaptation. Chronic pain, repeated exacerbations, disability and impact on activities of daily living and all other factors that affect disease course and prognosis and the patient, family and the surrounding community should be well knowledgeable about. A substantial proportion of participants in our study had negative attitudes against individuals with rheumatic diseases. Most of our participants reported not to marry, work or play with a person with a rheumatic disease, two third of them decided not to inform their contacts. The majority of the participants agreed to seek medical advice if they had a rheumatic disease. Yet other non-medical routes were also chosen by many of them such as buying some over the counter medicines; ask for physiotherapy; try herbal and alternative medicine measures or even ask for removing "evil spirits".

We found in our study that, awareness and knowledge of rheumatic diseases are significantly higher among females than in males and there is a steady increase in the awareness with the rise of education level, with a highly significant relation. Non-working and single participants had significantly higher knowledge compared to married or working ones. Concerning residence, urban people had the highest knowledge scores, followed by rural, and lastly those came from slum areas. Correlation between age and the knowledge and awareness score a highly significant negative correlation. This means that the older the age, the poorer the knowledge. There is a consensus in the previous publications, that higher education means more knowledge of the rheumatic diseases. ${ }^{7,11}$

Most of the literature denotes that age, sex and marital status and socioeconomic status are not related to the knowledge level. ${ }^{9}$ This can be explained by the relatively higher socioeconomic level of the selected sample in these studies and the choice of patients and not general populations besides, the variation of the questionnaire methodology among different studies.

Van der Wardt in his study showed that in general, knowledge about rheumatic diseases is limited. They undervalued the prevalence of rheumatic diseases and were oblivious of the different types. There is an incorrect belief that, poor diet and cold weather may trigger these diseases. He concluded that higher education and contact with patients with these diseases improve the knowledge obviously. The public classified rheumatic diseases as serious and they considered that patients are unable to alter disease progression. The participants in this study considered that the most serious complications of these groups of diseases were pain, deformities and dependency. Media purposes were positively correlated with knowledge, susceptibility, fear and behavioral intentions. This could clearly signifies the necessity and importance of using the media in improving knowledge and providing information on rheumatic diseases. $^{11}$

Potential for patients with lupus to experience cognitive dysfunction may impair the ability for an educational intervention to work effectively. Patient educational programs are key components of patient management strategies and improved quality of life for adults with chronic diseases patient educational programs vary greatly in their design and goals; minimal-tomoderate benefit from the group-based, psycho educational and psychotherapeutic patient education programs were presented. Specifically, cognitive, psychological, support and coping outcomes - the nonmedical factors - were improved more often than lupus disease damage or activity. Studies about the cost of each approach are limited. because of the diverse social, cultural and geographic differences of the 
patients with lupus, the programs must be designed to meet the needs of the target population. Do patients gain information that is more beneficial from trained professionals or well-designed self-administered programs? Similarly, given the significant increase in technology; (What technological advances could enhance currently available approaches?). A second issue relates to what specific information is key and most relevant to patients with lupus. "Should patient educational programs emphasize disease-specific knowledge, general disease symptomology, self-efficacy, depression and other mental health symptoms, selfmanagement, or all of the aforementioned issues?" Likewise, it is unclear which elements are most salient in lupus patient educational, Internet based education, TV or direct contact, specifically to affected population or general role of physician.

\section{Conclusions}

The awareness, knowledge and attitude of upper Egyptian population regarding rheumatic diseases are limited and deficient, thus widespread mass educational and learning programs are needed. Education level, work, and residence were found to be the main factors affecting knowledge and attitude towards rheumatic diseases in our study.

Acknowledgment: All authors meet the ICMJE criteria for authorship for this article, take responsibility for the integrity of the work and have given final approval to the version to be published.

Funding: This research did not receive any specific grant from funding agencies in the public, commercial, or not-forprofit sectors.
1. A. Gibofsky, Overview of epidemiology, pathophysiology, and diagnosis of rheumatoid arthritis, The American journal of managed care 18(13 Suppl) (2012) S295302.

2. E.D. Ferucci, D.W. Templin, A.P. Lanier, Rheumatoid arthritis in American Indians and Alaska Natives: a review of the literature, Seminars in arthritis and rheumatism, Elsevier, 2005, pp. 662-667.

3. A. Usenbo, V. Kramer, T. Young, A. Musekiwa, Prevalence of arthritis in Africa: A systematic review and meta-analysis, PloS one 10(8) (2015) e0133858.

4. F. Rees, M. Doherty, M. Grainge, G. Davenport, P. Lanyon, W. Zhang, The incidence and prevalence of systemic lupus erythematosus in the UK, 1999-2012, Annals of the rheumatic diseases (2014) annrheumdis-2014-206334.

5. G. Ciancio, A. Bortoluzzi, M. Govoni, Epidemiology of gout and chondrocalcinosis, Reumatismo 63(4) (2011) 207-220.

6. C.-F. Kuo, M.J. Grainge, W. Zhang, M. Doherty, Global epidemiology of gout: prevalence, incidence and risk factors, Nature Reviews Rheumatology 11(11) (2015) 649-662.

7. M. Severo, R. Gaio, R. Lucas, H. Barros, Assessment of the general public's knowledge about rheumatic diseases: evidence from a Portuguese populationbased survey, BMC musculoskeletal disorders 11(1) (2010) 1.

8. R. Neame, A. Hammond, C. Deighton, Need for information and for involvement in decision making among patients with rheumatoid arthritis: a questionnaire survey, Arthritis Care \& Research 53(2) (2005) 249255.

9. S. Hennell, C. Brownsell, J. Dawson, Development, validation and use of a patient knowledge questionnaire (PKQ) for patients with early rheumatoid arthritis, Rheumatology 43(4) (2004) 467-471.

10. J. Hill, H. Bird, R. Hopkins, C. Lawton, V. Wright, The development and use of a patient knowledge questionnaire in rheumatoid arthritis, Rheumatology 30(1) (1991) 45-49.

11. E.M. Van Der Wardt, E. Taal, J.J. Rasker, The general public's knowledge and perceptions about rheumatic diseases, Annals

\section{References}


of the rheumatic diseases 59(1) (2000) 3238.

12. S. Salman, A. SAlnuaimi, N.A. Lateef, R. Kadhum, Assessment of Knowledge and Attitude in a Sample of Patients with Rheumatoid Arthritis and Its Association with Disease Activity and Severity: A CrossSectional Study, Open Journal of
Rheumatology and Autoimmune Diseases 4(04) (2014) 226.

13. K. Lama, J. Hubner, G. Malaga, J. Amez, E. Alarcón, R. Huamanchumo, A. Berrocal, A. Calvo, Systemic Lupus Erythematosus Outpatients Knowledge About Their Disease: 268, JCR: Journal of Clinical Rheumatology 12(4) (2006) S85. 